\title{
Cold Tolerance Evaluation in a Diallel among Open-pollinated Sweet Corn Cultivars
}

\author{
P. Revilla ${ }^{1}$, J.R. Hotchkiss ${ }^{2}$, and W.F. Tracy ${ }^{3}$ \\ Department of Agronomy, University of Wisconsin-Madison, WI 53706
}

Additional index words. Zea mays, maize, combining ability

\begin{abstract}
Many sweet corn hybrids germinate poorly and have low seedling vigor in cold soils. Sources of cold tolerance and an understanding of its inheritance would benefit sweet corn production. Our objective was to determine the genetics of cold tolerance among open-pollinated progenitors of modern sweet corn. Six open-pollinated sweet corn cultivars were used as parents of a diallel. The 15 crosses plus reciprocals, parents, and checks were evaluated in cold chambers. Growing conditions were 14 hours with light at $14{ }^{\circ} \mathrm{C}$, and 10 hours without light at $10^{\circ} \mathrm{C}$. Days to emergence, percent emergence, shoot dry weight, and root dry weight were recorded. The experiment was repeated in the greenhouse under warm conditions. Variation for cold tolerance was present among the crosses and cultivars. The variation was primarily due to general combining ability (GCA) effects, with specific combining ability (SCA) effects and reciprocal effects being significant for seedling dry mater. 'Howling Mob' had significant favorable GCAs for all cold tolerance traits and resulted in the most cold-tolerant hybrids. 'Country Gentleman' and 'Stowell's Evergreen' were the slowest emerging parents. Days to emergence under cold conditions was not correlated to days to emergence under warm conditions. The correlations between root weight (cold) and root weight (warm) and shoot weight (cold) and shoot weight (warm) were significant, positive, and relatively large. In this material it appears that seedling vigor under warm conditions could be used to predict seedling size under cold conditions.
\end{abstract}

In many sweet corn production areas, production is limited by poor seedling emergence and vigor in cold, wet soils. The minimum temperature for germination, emergence, and growth of corn is $\approx 9$ to $10{ }^{\circ} \mathrm{C}$ (Blacklow, 1972; Crevecoeur et al., 1983; Eagles and Hardacre, 1979)

Problems during emergence and early stages of development have been attributed to many factors, including reduced endosperm weight and level of carbohydrate reserves, poor pericarp integrity, and increased susceptibility to pathogens (Andrew, 1982; Styer and Cantliffe, 1983; Tracy, 2000). Sweet corn with the sugaryl (sul) genotype has less starch in the endosperm relative to starchy corn (Soberalske and Andrew, 1980). Supersweet (shrunken2, $s h 2)$ seed in which endosperm weight is less than half that of sul has even fewer carbohydrate reserves (Schmidt and Tracy, 1988). The effect of seed size on germination is complex and has been related to emergence, seedling weight, and other factors involved in early growth (Bockstaller and Girardin, 1994). Poor emergence and vigor observed in sweet corn is

\footnotetext{
Received for publication 27 Nov. 2001. Accepted for publication 10 June 2002. Contribution from the Wisconsin Agricultural Experiment Station. Research supported by the College of Agricultural and Life Sciences, Univ. of Wisconsin-Madison, and the Comision Interministerial de Ciencia y Tecnologia of Spain.

${ }^{1}$ Current address: Mision Biologica de Galicia, CSIC, Apartado 28, 36080 Pontevedra, Spain.

${ }^{2}$ Current address: Pioneer Hi-Bred, North Platte, NE.

${ }^{3}$ To whom reprint requests should be addressed. E-mail: wftracy@facstaff.wisc.edu
}

related to both biotic and abiotic factors (Tracy, 2000). Cracks in the pericarp can result in rapid imbibition and leakage of electrolytes from the seed. The leachate may stimulate the development of pathogenic fungi (Tracy, 2000).

While early planting of sweet corn may result in cold stress, early planting is often desirable due to several biological and economic advantages. In the upper Midwest, early planted corn escapes a number of important diseases, including common rust (Puccinia sorghi) and maize dwarf mosaic virus (Tracy, 2000), and is usually more resistant to lodging (Pendleton, 1965). Early planted sweet corn usually commands the highest price in the fresh market and allows processing factories to start processing early thereby increasing productivity per factory. Consequently, cold tolerant germplasm sources would be useful.

Several studies have been conducted to determine the relative amounts of genetic variability for cold tolerance in corn. Brooking (1990) evaluated rate of emergence of tropical corn, from Mexico and Peru, under cold conditions. He found that Mexican races adapted to $1800 \mathrm{~m}$ or higher had faster emergence than Peruvian germplasm. Eagles and Brooking (1981) examined corn from several cold areas, and found that the most cold-tolerant germplasm had highland Mexican origin. Haskell (1949) and Haskell and Singleton (1949) found that sul sweet corn is not necessarily less resistant to cold conditions than field corn. In contrast, Ordas et al. (1994) found sul hybrids lack early vigor in cold wet soils in northern Spain. Hotchkiss et al. (1997) evaluated the cold tolerance of 35 open-pollinated sweet corn cultivars, field corn synthetics, and high altitude germplasm. They found that certain sweet corn cultivars nearly equaled the performance of the high altitude material and exceeded the performance of field corn checks.

Few germplasm sources fit the strict commercial standards for sweet corn (Tracy, 2000). Moreover, tropical corn is unadapted to temperate conditions. Several open-pollinated sweet corn cultivars are publicly available. Revilla and Tracy (1995a, 1995b) classified 58 of these cultivars based on morphology, pedigree, and molecular markers. In a separate study they (Revilla and Tracy, 1997) identified two latent heterotic patterns. 'Country Gentleman' by 'Northern Flint' cultivars 'Golden Bantam', 'Pease Crosby', and 'Lindsey Meyer Blue' is a strong heterotic pattern. A secondary pattern involves 'Stowell's Evergreen'by 'Golden Bantam', 'Pease Crosby', and 'Lindsey Meyer Blue'. Since these cultivars include the progenitors of modern sweet corn germplasm, they are a primary source to study the genetics of cold tolerance in sweet corn. Our objective was to determine genetics of cold tolerance among open-pollinated progenitors of modern sweet corn.

\section{Materials and Methods}

Six open-pollinated sweet corn cultivars were used as parents: 'Country Gentleman', 'Golden Bantam', 'Lindsey Meyer Blue', and 'Stowell's Evergreen' from a sweet corn collection maintained by the College of Agricultural and Life Sciences, Univ. of Wisconsin-Madison; 'Howling Mob' (SS IA DR G) from the Seed Savers collection (Adelman et al., 1993); and 'Pease Crosby' (PI 255983) from the North Central Plant Introduction Center, Ames, Iowa. These cultivars represent diverse and historically important germplasm. Four checks were also included: 'Maiz Dulce', 'WCDNTS', 'NS-CT', and the commercial sul hybrid 'Jubilee'. 'Maiz Dulce' is a high-altitude Mexican land race homozygous for sul. 'WCDNTS' (sul) was developed at the Univ. of Wisconsin-Madison and contains 50\% 'Cacahuacintle Dulce' (high-altitude Mexican germplasm) and 50\% temperate sweet germplasm. 'NS-CT' is a Nebraska field corn synthetic developed for cold tolerance. In a previous screening study we had determined that these cultivars represent a range of response to cold tolerance (Hotchkiss et al., 1997).

Seed was produced for all populations and hybrids in one year and in one location to reduce environmental effects on seed quality. 'Jubilee' was produced commercially. All populations were grown on Plano silt loam (fine-silty, mixed, mesic Typic Argiudolls) at the West Madison Agricultural Research Station in Summer 1993. Nursery rows were over-planted by machine and thinned to 15 plants per row. Rows were $5.3 \mathrm{~m}$ in length with $0.76 \mathrm{~m}$ between rows.

Adiallel cross (method II of Griffing, 1956) was made among the six cultivars, in 1993. For each cross, pollen from 25 plants from 
one cultivar was bulked. The pollen bulk was used to pollinate 25 plants from the second cultivar. This was done twice so at least 50 plants from each cultivar were used to make each cross.

The 15 hybrids plus reciprocals, six parents, and four checks were planted in $27 \times$ 54-cm trays filled with autoclaved sand, in two growth chambers (Percival Manufacturing Corp., Boone, Iowa). Each chamber had four shelves. The experimental design was a randomized complete block with seven replications. A replication consisted of two plastic trays placed on one shelf. Temperatures within the growth chambers were $14 \pm 1^{\circ} \mathrm{C}$ and $10 \pm 1$ ${ }^{\circ} \mathrm{C}$ for 14-h days and 10-h nights, respectively. These temperatures were chosen because they were slightly higher than the minimum temperature for corn growth (Blacklow, 1972; Crevecoeur et al., 1983; Eagles and Hardacre, 1979) and allowed measurable growth on entries in a previous study (Hotchkiss et al., 1997). Fluorescent light was provided for $14 \mathrm{~h}$ per day. Five kernels per plot from each entry were weighed and planted. In an attempt to control seed rotting pathogens, kernels were dusted with captan ( $N$-[(trichloromethyl) thio] 4-cyclohexene-1,2-dicarboximide) before planting. Kernels were planted $\approx 2.5 \mathrm{~cm}$ deep. Trays were fertilized with "Peter's" solution (20-20-20) and covered with clear plastic tops to maintain moisture. To minimize effect of location within the growth chamber, the two trays comprising each replication were rearranged as a unit within chambers. Trays were moved on a daily basis during the first $14 \mathrm{~d}$ after planting, then every other day until the experiment was terminated.

Traits measured were: days to emergence, percent emergence, and seedling root and shoot dry weight. Stand counts were recorded every $2 \mathrm{~d}$ until $42 \mathrm{~d}$ after planting. These counts were used to calculate average days to emergence (Hotchkiss et al., 1997; Smith and Millet, 1964).

Stand counts at $42 \mathrm{~d}$ after planting were used to calculate percent emergence. Seedlings were removed from trays on a per plot basis, rinsed in water, separated into roots and shoots, bagged, and dried for $7 \mathrm{~d}$ at $120{ }^{\circ} \mathrm{C}$ before weighing.

The warm evaluation followed the cold evaluation experimental procedure as described above, except the entries were grown in a greenhouse at $\approx 24 \pm 2{ }^{\circ} \mathrm{C}$. Stand counts were made every day until $12 \mathrm{~d}$ after planting. Percent and days to emergence, and root and shoot weights were obtained as described above.

Individual analyses of variance (ANOVAs) were performed for each trait for both cold and warm experiments. Covariance analyses, using kernel weight as independent variable, were performed for each trait, and the relative efficiency of the covariance analysis was decided following Gomez and Gomez (1984).

Two ANOVAs were performed. One included hybrids, reciprocals, parents, and checks. The other, with the hybrids plus reciprocals, was used to investigate combining abilities and reciprocal effects. Combining abilities and reciprocal effects, for the cold evaluation, were computed using the program "Diallel analysis and simulation" (Burow and Coors, 1994). Cultivar effects were considered fixed. Phenotypic correlations between traits under cold and warm conditions were computed. SAS was used for ANOVA and covariance, mean comparisons including checks, and correlation analysis (SAS, 1989).

Entries were ranked based on their performance in the cold environment using a rank-summation index with a scale of 1 to 40, allowing for ties (Mock and Skrlda, 1978). This index was obtained by first ranking means of days to emergence, and root and shoot weight. The rank of 1 represented the entry with the most desirable mean for that trait. Second, the ranks of the traits were summed for each entry. The sum was divided by three. A smaller index value indicated more cold tolerance.

\section{Results and Discussion}

In the ANOVA including parents and checks under cold conditions, entries differed for days to emergence and root and shoot dry weight but not for percent emergence. Entries also differed for kernel weight, thus covariance analyses were performed for the three cold tolerance traits on kernel weight. Days to emergence did not covary significantly with kernel weight. Root and shoot weight covaried significantly with kernel weight, but not enough to justify the use of kernel weight as covariate in subsequent analysis (Gomez and Gomez, 1984).

When confronted with columns of individual numbers relating to the same trait, a rank summation index is useful for summarizing data. Entries ranged from 'WCDNTS' ( 1 , most cold tolerant) to 'Country Gentleman' (40, least cold tolerant) (Table 1). 'WCDNTS' was followed by two 'Howling Mob' hybrids, 'Maiz Dulce', and 'Howling Mob'. The rank summation index makes 'Howling Mob's' genetic contribution to cold tolerance quite clear. Nine of the top 14 hybrids have 'Howling Mob' as a parent. However, the 15 least cold tolerant hybrids had either 'Country Gentleman' or 'Stowell's Evergreen' as a parent. Based on the index, 'Country Gentleman' was the least cold tolerant entry in the experiment, followed closely by 'Jubilee' and 'NS-CT'.

The fastest emerging hybrids were 'Howling Mob' X 'Lindsey Meyer' and its reciprocal (Table 1). The cold tolerant checks 'WCDNTS' and 'Maiz Dulce', having Mexican high altitude germplasm, 'Pease Crosby' and a number of hybrids were not significantly slower emerging than 'Howling Mob' $x$ 'Lindsey Meyer'. The slowest emerging hybrid was 'Stowell's Evergreen' x 'Country Gentleman', followed closely by its parents 'Stowell's Evergreen' and 'Country Gentleman'. The Nebraska cold tolerant synthetic, 'NS-CT', 'Jubilee', and 'Golden Bantam' did not differ from 'Stowell's Evergreen' (Table 1). This is consistent with our initial screening experiment (Hotchkiss et al., 1997). Days to emergence for temperate sweet corn cultivars were similar to cold tolerant checks and significantly better than the commercial hybrid 'Jubilee'. Many $\mathrm{s} u 1$ entries also exceeded 'NS-CT'. This result agreed with Haskell (1949) and Haskell and Singleton (1949). Murray and Cooper (1967) concluded that the growing embryo and seedling are effectively tolerant to cold as long as the endosperm was not fully utilized. This implies that cold soil conditions are not necessarily a disadvantage if the seedling grows rapidly.

'WCDNTS', 'Maiz Dulce', 'Golden Bantam' $x$ 'Howling Mob', and 'Stowell's Evergreen' $x$ 'Howling Mob' had the heaviest roots. 'Golden Bantam' and 'Howling Mob' were not significantly different from 'Maiz Dulce' for root weight. 'Stowell's Evergreen', 'Country Gentleman', 'NS-CT', and 'Jubilee' were among the entries having the lightest roots (Table 1).

'Howling Mob' $x$ 'Pease Crosby' had the heaviest shoots. 'Howling Mob' ranked second for shoot size and was not significantly smaller than 'Howling Mob' $x$ 'Pease Crosby' (Table 1 ). The shoots of the cold tolerant checks, 'WCDNTS' and 'Maiz Dulce', were significantly smaller than those of 'Howling Mob'. 'Country Gentleman', 'Jubilee', and 'Golden Bantam' $x$ 'Stowell's Evergreen' had the lightest shoots. 'Stowell's Evergreen' and 'NS-CT' had slightly heavier shoots and ranked just above the lightest. Relative to shoots, roots play a greater role in cold tolerance (Blum, 1988).

Under cold conditions days to emergence, root weight, and shoot weight were all correlated (Table 2). Negative correlations indicate that the more rapidly germinating entries had heavier shoots and roots. Stamp (1984) found a positive association between days to emergence and seedling vigor under cold conditions. Keim and Gardner (1984) found significant positive correlations between seedling dry weight or vigor and emergence proportion under cold conditions. On the other hand, Mock and Eberhart (1972) found that the rate of cold emergence was not positively correlated with seedling dry matter. Correlations among these traits depend on the nature of the genetic material and the environmental conditions (Blum, 1988).

The correlation between root weight and shoot weight was relatively large and indicates it may be possible to select for improved root weight indirectly by selecting for heavier shoots. Given the greater time and effort required to collect data on roots this may be worthwhile. On the other hand the correlations between root and shoot weight and days to emergence, while significant, were relatively small and indicate that both weight and emergence rate should be selected.

Under warm conditions, entries varied for days to emergence, and shoot and root weight but not percent emergence (Table 1). Cold days to emergence was uncorrelated with warm days to emergence indicating the necessity for evaluation under cold conditions (Table 2). The correlations between cold root weight and warm root weight and cold and warm shoot weight were relatively high and indicate that these traits could be selected under either warm or cold conditions with indirect gain expected for the alternative condition (Table 2). 
Table 1. Means days to emergence and root and shoot weight under cold and warm conditions for 40 sweet corn entries, including 15 hybrids, 15 reciprocals, six parents, and four checks.

\begin{tabular}{|c|c|c|c|c|c|c|c|}
\hline Genotype $^{z}$ & Rank & $\begin{array}{c}\text { Days } \\
\text { emerg. } \\
(\text { coldy) }\end{array}$ & $\begin{array}{c}\text { Root } \\
\text { wt } \\
\left(\text { cold }^{y}\right)\end{array}$ & $\begin{array}{c}\text { Shoot } \\
\text { wt } \\
\left(\text { cold }^{y}\right)\end{array}$ & $\begin{array}{c}\text { Days } \\
\text { emerg. } \\
\left(\text { warm }^{x}\right)\end{array}$ & $\begin{array}{c}\text { Root } \\
\text { wt } \\
\left(\text { warm }^{x}\right)\end{array}$ & $\begin{array}{c}\text { Shoot } \\
\text { wt } \\
\left(\text { warm }^{x}\right)\end{array}$ \\
\hline WCDNTS & 1 & 16.2 & 0.178 & 0.196 & 5.7 & 0.350 & 0.382 \\
\hline GBXHM & 2 & 17.3 & 0.154 & 0.209 & 5.9 & 0.325 & 0.386 \\
\hline HMXLM & 3 & 15.7 & 0.123 & 0.229 & 6.0 & 0.343 & 0.457 \\
\hline HM & 4 & 17.7 & 0.148 & 0.234 & 6.0 & 0.352 & 0.396 \\
\hline Maiz Dulce & 5 & 16.5 & 0.154 & 0.175 & 6.2 & 0.373 & 0.370 \\
\hline LMXHM & 6 & 15.8 & 0.132 & 0.191 & 5.9 & 0.295 & 0.305 \\
\hline GBXLM & 7 & 17.5 & 0.130 & 0.220 & 5.8 & 0.320 & 0.390 \\
\hline LMXPC & 8 & 16.3 & 0.119 & 0.206 & 5.7 & 0.324 & 0.356 \\
\hline HMXPC & 9 & 18.4 & 0.140 & 0.236 & 6.0 & 0.394 & 0.425 \\
\hline HMXCG & 10 & 18.5 & 0.145 & 0.206 & 6.3 & 0.352 & 0.334 \\
\hline HMXGB & 10 & 18.2 & 0.144 & 0.203 & 6.3 & 0.301 & 0.337 \\
\hline HMXSE & 10 & 17.8 & 0.146 & 0.187 & 6.2 & 0.346 & 0.351 \\
\hline GBXPC & 13 & 18.0 & 0.129 & 0.213 & 6.8 & 0.283 & 0.342 \\
\hline LMXGB & 13 & 16.7 & 0.117 & 0.192 & 5.7 & 0.245 & 0.301 \\
\hline PCXGB & 15 & 16.8 & 0.130 & 0.166 & 6.0 & 0.243 & 0.258 \\
\hline SEXHM & 16 & 18.6 & 0.153 & 0.167 & 6.0 & 0.245 & 0.284 \\
\hline PCXHM & 17 & 17.0 & 0.115 & 0.175 & 6.0 & 0.300 & 0.282 \\
\hline $\mathrm{PC}$ & 18 & 16.5 & 0.097 & 0.175 & 6.0 & 0.245 & 0.304 \\
\hline PCXLM & 18 & 17.5 & 0.110 & 0.183 & 5.8 & 0.242 & 0.281 \\
\hline GB & 20 & 20.2 & 0.140 & 0.192 & 6.2 & 0.320 & 0.363 \\
\hline GBXCG & 20 & 19.0 & 0.138 & 0.179 & 6.1 & 0.258 & 0.292 \\
\hline PCXCG & 22 & 17.0 & 0.111 & 0.133 & 5.5 & 0.196 & 0.235 \\
\hline SEXLM & 23 & 19.0 & 0.129 & 0.166 & 6.6 & 0.285 & 0.330 \\
\hline CGXGB & 24 & 17.6 & 0.115 & 0.136 & 5.3 & 0.214 & 0.263 \\
\hline SEXPC & 25 & 18.8 & 0.123 & 0.159 & 5.9 & 0.294 & 0.304 \\
\hline CGXPC & 26 & 17.6 & 0.102 & 0.135 & 5.8 & 0.169 & 0.224 \\
\hline CGXLM & 27 & 18.1 & 0.103 & 0.146 & 5.7 & 0.285 & 0.277 \\
\hline SEXGB & 27 & 19.3 & 0.126 & 0.141 & 5.8 & 0.290 & 0.315 \\
\hline LM & 29 & 17.6 & 0.082 & 0.160 & 6.2 & 0.290 & 0.343 \\
\hline PCXSE & 30 & 17.8 & 0.099 & 0.130 & 5.6 & 0.225 & 0.250 \\
\hline LMXSE & 31 & 19.4 & 0.105 & 0.139 & 5.7 & 0.222 & 0.248 \\
\hline CGXHM & 32 & 18.3 & 0.093 & 0.130 & 5.7 & 0.307 & 0.269 \\
\hline LMXCG & 33 & 19.3 & 0.090 & 0.139 & 5.8 & 0.227 & 0.251 \\
\hline SEXCG & 34 & 23.4 & 0.119 & 0.128 & 6.5 & 0.243 & 0.256 \\
\hline CGXSE & 35 & 18.9 & 0.084 & 0.132 & 5.9 & 0.228 & 0.260 \\
\hline SE & 36 & 21.5 & 0.112 & 0.124 & 6.2 & 0.291 & 0.284 \\
\hline GBXSE & 37 & 20.8 & 0.085 & 0.101 & 5.8 & 0.205 & 0.213 \\
\hline NS-CT & 38 & 20.6 & 0.060 & 0.127 & 5.8 & 0.252 & 0.281 \\
\hline Jubilee & 38 & 20.4 & 0.082 & 0.087 & 5.5 & 0.216 & 0.242 \\
\hline $\mathrm{CG}$ & 40 & 21.1 & 0.064 & 0.086 & 5.9 & 0.161 & 0.190 \\
\hline $\operatorname{LSD}(5 \%)$ & --- & 1.9 & 0.030 & 0.027 & 0.6 & 0.165 & 0.138 \\
\hline
\end{tabular}

${ }^{\mathrm{z}} \mathrm{CG}=$ Country Gentleman, GB = Golden Bantam, HM = Howling Mob, LM = Lindsey Meyer Blue, $\mathrm{PC}=$ Pease Crosby, and SE = Stowell's Evergreen.

yeans under cold conditions.

${ }^{\mathrm{x}}$ Means under warm conditions.

Table 2. Phenotypic correlation coefficients for days to emergence, and root and shoot dry weight under cold $\left(14 / 10^{\circ} \mathrm{C}\right)$ and warm $\left(24^{\circ} \mathrm{C}\right)$ conditions from a diallel among six open pollinated sweet corn cultivars, including reciprocals and parents and four checks $(\mathrm{N}=40)$

\begin{tabular}{lccccc}
\hline & $\begin{array}{c}\text { Root } \\
\text { wt } \\
\text { (cold) }\end{array}$ & $\begin{array}{c}\text { Shoot } \\
\text { wt } \\
\text { (cold) }\end{array}$ & $\begin{array}{c}\text { Days to } \\
\text { emergence } \\
\text { (warm) }\end{array}$ & $\begin{array}{c}\text { Root } \\
\text { wt } \\
\text { (warm) }\end{array}$ & $\begin{array}{c}\text { Shoot } \\
\text { wt } \\
\text { (warm) }\end{array}$ \\
\hline Days to emergence (cold) & $-0.39^{* * *}$ & $-0.59^{* *}$ & 0.21 & $-0.34^{*}$ & $-0.45^{* *}$ \\
Root weight (cold) & & $0.73^{* *}$ & $0.36^{*}$ & $0.67^{* *}$ & $0.66^{* *}$ \\
Shoot weight (cold) & & & $0.37^{*}$ & $0.76^{* *}$ & $0.87^{* *}$ \\
Days to emergence (warm) & & & $0.38^{*}$ & $0.35^{*}$ \\
Root weight (warm) & & & $0.89^{* *}$ \\
Shoot weight (warm) & & & & \\
*,** Significant at the 0.05 and 0.01 levels, respectively.
\end{tabular}

Table 3. Hybrids, general (GCA) and specific (SCA) combining abilities, reciprocal effects and error mean squares for four cold tolerance related traits and kernel weight, from the analysis of variance of a diallel among six open-pollinated sweet corn cultivars.

\begin{tabular}{lccccc}
\hline & \multicolumn{4}{c}{ Mean squares } \\
\cline { 2 - 6 } Trait & Hybrids & GCA & SCA & Reciprocals & Error \\
\hline Days to emergence & $22.080^{* *}$ & $75.939^{* *}$ & 9.092 & 11.920 & 6.994 \\
Emergence (\%) & 361.576 & --- & --- & --- & --- \\
Root weight (g) & $0.003^{* *}$ & $0.007^{* *}$ & 0.001 & $0.002^{* *}$ & 0.001 \\
Shoot weight $(\mathrm{g})$ & $0.009^{* *}$ & $0.031^{* *}$ & $0.003^{* *}$ & $0.006^{* *}$ & 0.001 \\
\hline
\end{tabular}

** Significant at the 0.01 level.
Genotype xenvironment interaction is often large in cold tolerance studies (Blum, 1988; Mock and Eberhart, 1972). Blum explains that interactions could be a result of biotic factors in the field. Andrew (1954) found that the ranking of genotypes reversed in infected and sterilized soils. In our experiment, we used sterilized sand in both environments and seed lots produced under identical conditions. While we did not analyze the warm and cold environments in the same ANOVA these factors would reduce changes in genotype rankings under cold and warm conditions.

In the ANOVA without the checks under cold conditions, entries differed for days to emergence, and root and shoot weight. Entries did not differ for percent emergence, thus the diallel analysis was not performed for this trait. General combining ability was significant for days to emergence, and root and shoot weight (Table 3). Mainly additive genetic effects with no reciprocal effects conditioned days to emergence. Reciprocal effects were significant for root and shoot weight. Specific combining ability was significant for shoot weight. Many researchers (see Blum, 1988, for a review) have found that mostly additive effects control these traits, though dominance effects are sometimes significant, and reciprocal effects are usually significant.

The cultivars derived from the race 'Northern Flint'; 'Golden Bantam', 'Howling Mob', 'Lindsey Meyer', and 'Pease Crosby', had negative general combining abilities (GCAs) for days to emergence (Table 4). A negative GCA indicates that the parent resulted in faster emerging hybrids. 'Stowell's Evergreen' and 'Country Gentleman', which may have 'Southern Dent' germplasm in their background, had large positive GCAs indicating their progeny emerged more slowly. Likewise all the "Northern Flint' types had positive GCAs for shoot weight although all were not different from zero. 'Howling Mob' had the largest GCA for shoot weight indicating that its progeny had the heaviest shoots. Both 'Stowell's Evergreen' and 'Country Gentleman' had negative GCA for this trait, with 'Country Gentleman' resulting in the smallest shoots. For root weight the northern cultivars were not consistent and two of the cultivars had negative GCA along with 'Stowell's Evergreen' and 'Country Gentleman'. 'Howling Mob' and 'Golden Bantam' had positive GCA.

When GCA for all three traits was considered it was clear that 'Howling Mob' had favorable GCA for all three cold tolerance traits. The contributions of the other northern cultivars was less consistent, 'Pease Crosby', for example, contributed rapid emergence, but had a negative GCA for root weight and a nonsignificant GCA for shoot weight. 'Stowell's Evergreen' and 'Country Gentleman' had unfavorable GCA for all traits.

Sweet corn parents and hybrids in this diallel varied for cold tolerance and had a range comparable to the checks. Mock and Eberhart (1972) also found wide ranges for cold tolerance in a set of well-adapted maize populations. High altitude Mexican races have been shown to have the greatest potential for 
Table 4. General combining ability of six open-pollinated sweet corn cultivars on three cold related traits, from a diallel grown under cold conditions.

\begin{tabular}{|c|c|c|c|c|c|c|c|c|}
\hline rait & $\begin{array}{c}\text { Country } \\
\text { Gentleman }\end{array}$ & $\begin{array}{l}\text { Golden } \\
\text { Bantam }\end{array}$ & $\begin{array}{c}\text { Howling } \\
\text { Mob }\end{array}$ & $\begin{array}{c}\text { Lindsey } \\
\text { Meyer }\end{array}$ & $\begin{array}{c}\text { Pease } \\
\text { Crosby }\end{array}$ & $\begin{array}{c}\text { Stowell's } \\
\text { Evergreen }\end{array}$ & $\mathrm{LSD}^{\mathrm{Z}}$ & $\mathrm{SE}^{\mathrm{y}}$ \\
\hline av & $1 .($ & -0.1514 & -0.4846 & -0.9133 & -1.2365 & 1.7663 & 1.0316 & 0.3226 \\
\hline ht $(\mathrm{g})$ & -0.0270 & 0.0074 & 0.0316 & 0.0143 & 0.0017 & -0.0280 & 0.0126 & 0.0039 \\
\hline Root weight (g) & -0.0114 & 0.0070 & 0.0188 & -0.0056 & -0.0060 & -0.0028 & 0.0124 & 0.0039 \\
\hline
\end{tabular}

${ }^{\mathrm{z}}$ Least significant difference at $P=0.05$.

yStandard error.

improving cold tolerance (Brooking, 1990; Eagles and Brooking, 1981). 'Howling Mob' and some of its hybrids compared favorably with the Mexican high altitude checks in this study. Inbreds derived from the cultivar 'Golden Early Market', which comes from a cross of 'Golden Bantam' and 'Howling Mob', are still in use today. 'Howling Mob' is well adapted to temperate conditions and could be useful as a source of cold tolerance in temperate breeding programs.

\section{Literature Cited}

Adelman, A., S. Demunth, B. Idstrom, J. Thuente, and K. Whealy. 1993. Seed Savers 1993 Yearbook. K. Whealy (ed.). Decorah, Iowa.

Andrew, R.W. 1954. Breeding maize for cold resistance. Euphytica 3:108.

Andrew, R.H. 1982. Factors influencing early seedling vigor of shrunken-2 maize. Crop Sci. 22:263.

Blum, A. 1988. Plant breeding for stress environments. CRC Press, Boca Raton, Fla.

Blacklow, W.M. 1972. Influence of temperature on germination and elongation of the radicle and shoot of corn (Zea mays L.) Crop Sci. 12: 647-650.

Bockstaller, C. and P. Girardin. 1994. Effects of seed size on maize growth from emergence to silking. Maydica 39:213-218.

Brooking, I.R. 1990. Variation amongst races of maize from Mexico and Peru for seedling emergence time at low soil temperatures. Maydica 35:35-40.

Burow, M.D. and J.G. Coors. 1994. Diallel: a microcomputer program for the simulation and analysis of diallel crosses. Agron. J. 86: 154-158.

Crevecoeur, M., R. Deltour, and R. Bronchart. 1983. Effects of subminimal temperature on physiology and ultrastructure of Zea mays embryo during germination. Can. J. Bot. 61: $1117-1125$.

Eagles, H.A. and I.R. Brooking. 1981. Populations of maize with more rapid and reliable seedling emergence than Corn Belt Dents at low temperatures. Euphytica 30:755-763.

Eagles, H.A. and A.K. Hardacre. 1979. Genetic variation in maize (Zea mays L.) for germination and emergence at $10{ }^{\circ} \mathrm{C}$. Euphytica. 28:287-295.

Gomez, K.A. and A.A. Gomez. 1984. Statistical procedures for agricultural research. 2nd ed. Wiley, Singapore.

Griffing, B. 1956. Concept of general and specific combining ability in relation to diallel crossing systems. Aust. J. Biol. Sci. 9:463-493.

Haskell, G. 1949. Studies with sweet corn. I. Cold treatment and germination. Plant and Soil II. 1:49-57.

Haskell, G. and W.R. Singleton. 1949. Use of controlled low temperature in evaluating the cold hardiness of inbred and hybrid maize. Agron. J. 41:34-40.

Hotchkiss, J.R., P. Revilla, and W.F. Tracy. 1997. Cold tolerance among open-pollinated sweet corn cultivars. HortScience 32:719-723.

Keim, K.R. and C.O. Gardner. 1984. Genetic variation for cold tolerance in selected and unselected maize populations. Field Crops Res. 8:143.

Mock, J.J. and S.A. Eberhart. 1972. Cold tolerance in adapted maize populations. Crop Sci. 12:466.

Mock, J.J. and W.H. Skrdla. 1978. Evaluations of maize plant introductions for cold tolerance. Euphytica 27:27-32.

Murray, G.A. and C.S. Cooper. 1967. Endosperm utilization in relation to cold tolerance of orchard grass seedlings. Agron. J. 59:253.

Ordas, A., P. Revilla, R.A. Malvar, and M.E. Cartea. 1994. Development of sweet corn hybrids adapted to the environmental conditions of the Northwest of Spain. Maydica 39: 171-175.

Pendleton, J.W. 1965. Cultural practices-Spacing, etc. Proc. 20th Annu. Hybrid Corn Industry Res. Conf. p. 51-58.

Revilla, P. and W.F. Tracy. 1995a. Morphological characterization and classification of open-pollinated sweet corn cultivars. J. Amer. Soc. Hort. Sci. 120:112-118.

Revilla, P. and W.F. Tracy. 1995b. Isozyme variation and phylogenetic relationships among open-pollinated sweet corn cultivars. Crop Sci. 35:19-227.

Revilla, P. and W.F. Tracy. 1997. Heterotic patterns among open-pollinated sweet corn cultivars. J. Amer. Soc. Hort. Sci. 122:319-324.

SAS Institute. 1989. SAS/STAT user's guide. Version 6.09. SAS, Cary, N.C.

Schmidt, D.H. and W.F. Tracy. 1988. Endosperm type, inbred background, and leakage of seed electrolytes during imbibition in sweet corn. J. Amer. Soc. Hort. Sci. 113:269.

Smith, P.G. and A.H. Millet. 1964. Germinating and sprouting responses of the tomato at low temperatures. J. Amer. Soc. Hort. Sci. 84: 480-484.

Soberalske, R.M. and R.H. Andrew. 1980. Gene effects on water soluble polysaccharides and starch of near-isogenic lines of sweet corn. Crop Sci. 20:201.

Stamp, P. 1984. Emergence and seedling growth of tropical highland maize and its topcrosses with Middle European hybrids. Z. Acker Pflanzenbau 153:116.

Styer, R.D. and D.J. Cantliffe. 1983. Changes in seed structure and composition during development and their effects on leakage in two endosperm mutants of sweet corn. J. Amer. Soc. Hort. Sci. 108:721.

Tracy, W.F. 2000. Sweet corn, p. 155-199. In: A.R. Hallauer (ed.). Specialty corns. CRC Press, Boca Raton, Fla. 